\title{
Seismic facies analysis of thin sandstone reservoirs, North Western Desert, Egypt
}

\author{
Farouk I. Metwalli ${ }^{1}$ El-Arabi H. Shendi ${ }^{2} \cdot$ Mohamed S. Fagelnour $^{3}$
}

Received: 11 December 2017 / Accepted: 9 May 2018 / Published online: 18 September 2018

(c) The Author(s) 2018

\begin{abstract}
The detection of thin sandstone reservoirs on seismic sections is a matter of seismic resolution and bed thickness. Usually, layers thinner than $50 \mathrm{ft}$. thick are difficult to visualize on vertical seismic sections. The problem is observed in the northwestern desert of Egypt, where several thin oil-bearing sandstone reservoirs are located, among them Qasr Field which produces oil from the Lower Cretaceous Alam El Bueib Formation, specially unit AEB-3D (D2). The aim is to follow unit (D2) sandstone channels using available horizontal and vertical seismic sections coupled with other well logs and well data. The analytical method includes interpreting lithostratigraphic units from wells logs, mapping sandstone channels, generating synthetic seismograms and correlation with stratigraphy from wells, and finally to detect channels on seismic sections using positive and negative amplitudes with proper time slice. Finally, results show that, although unit AEB-3D (D2) sandstone is $\pm 50 \mathrm{ft}$. thick, it can be detected using seismic modeling and well data with some efficiency.
\end{abstract}

Keywords Seismic facies analysis · Thin sandstone reservoirs · Qasr Field · Western Desert · Egypt

\section{Introduction}

The northwestern desert is an important oil and gas province in Egypt. The reservoir units range in geologic age from Paleozoic to Cenozoic, where the western desert is mostly covered by the great Upper Miocene limestone plateau (Said 1962; WEC 1984, 1995, EGPC 1992). Qasr field is located in eastern Shoushan basin, between Lat.: $30^{\circ} 39^{\prime} 24.296^{\prime \prime} \mathrm{N}$, $30^{\circ} 34^{\prime} 56.70^{\prime \prime} \mathrm{N}$, and Long.: $26^{\circ} 38^{\prime} 04.9796^{\prime \prime} \mathrm{E}, 26^{\circ} 45^{\prime} 56.64^{\prime \prime} \mathrm{E}$ (Fig. 1). Shoushan basin, which is located to the south of Matrouh basin, shows the effect of ENE-WSW and WNW-ESE oriented faults on the basin geometry. Like Matrouh basin, Shoushan basin witnessed Jurassic and Early Cretaceous extensions followed by Late Cretaceous early Tertiary inversion (El Awdan et al. 2002). NE-SW and NNE-SSW oriented inversion anticlines as well as tilted

Farouk I. Metwalli

pine_egypt@hotmail.com

1 Geology Department, Faculty of Science, Helwan University, Cairo, Egypt

2 Geology Department, Faculty of Science, Suez Canal University, Ismailia, Egypt

3 Khalda Petroleum Company, Cairo, Egypt fault blocks bounded by WNW-ESE and NW-SE oriented normal faults form the main structural traps in the basin (Moustafa 2008). Many oil and gas fields, discovered in Shoushan basin, were charged by source rocks of Jurassic age (e.g. Umbarka, El-Qasr, Khepri, Sethos, Renpet, Kalabsha, Meleiha). Qasr field was discovered in 2003. It produces gas from the Jurassic Khatatba Formation (Lower Safa unit) and oil from several levels in the Lower Cretaceous Alam El Bueib Formation, and Upper Cretaceous Bahariya formation. The detection of thin sandstone reservoir units on seismic, in the Shoushan basin, was reported by Othman and Metwalli (2000), Metwalli and El Maadawy (2005), Metwalli and Bakr (2007). They concluded that the depositional model for AEB-D1 can be considered as a barrier bar, and the effect of seismic resolution limits the ability to determine the effects of lithology, structure, or stratigraphy on the peak amplitude data.

\section{Data and methods}

For this study, we selected three vertical seismic sections and one horizontal time slice, from a 3D seismic cube covering Qasr Field. The seismic data have a reverse polarity with seismic bandwidth $(10-70 \mathrm{~Hz})$. We used electric well logs 
from ten wells and core description from two wells was used in the lithological and Paleo-environmental interpretations (Fig. 2). In addition, one seismic attribute map was constructed from AEB-3D (D2) time map interpretation using the Schlumberger Petrel software. The method comprises of lithological interpretation from well logs, mapping sand channels and bars, generating synthetic seismograms and detection of sandstone on horizontal and vertical seismic sections.

Table 1 Thickness, density, sonic and interval velocity of the Alam El Bueib-3D (D2) sandstone unit

\begin{tabular}{lllll}
\hline Well name & $\begin{array}{l}\text { Sand } \\
\text { thickness } \\
(\mathrm{ft} .)\end{array}$ & $\begin{array}{l}\text { Density }(\mathrm{g} / \\
\left.\mathrm{cm}^{3}\right)\end{array}$ & $\begin{array}{l}\text { Sonic }(\Delta t)(\mu \mathrm{s} / \\
\mathrm{ft} .)\end{array}$ & $\begin{array}{l}\text { Interval } \\
\text { velocity } \\
(\mathrm{ft} . / \mathrm{s})\end{array}$ \\
\hline Qasr-03 & 12 & 2.57 & 63.5 & 14,985 \\
Qasr-07 & 35 & 2.56 & 64 & 14,394 \\
Qasr-10 & 48 & 2.41 & 66.5 & 15,135 \\
Qasr-31 & 24 & 2.42 & 67.5 & 15,142 \\
Qasr-36 & 32 & 2.46 & 62 & 13,888 \\
Qasr-41 & 53 & 2.43 & 64.7 & 13,889 \\
Qasr-42 & 5 & 2.52 & 53.13 & 15,136 \\
Qasr-45 & 16 & 2.47 & 62.5 & 14,707 \\
Qasr-48 & 35 & 2.5 & None & 13,880 \\
Qasr-49 & 18 & 2.41 & 66.6 & 15,151 \\
\hline
\end{tabular}

\section{Geologic setting}

The stratigraphic column of the northwestern desert ranges in age from Paleozoic to recent. The deeper well in Qasr Field penetrated only Middle Jurassic Khatatba Formation and no Paleozoic units were reported (Fig. 3). Khatatba Formation is divided into three lithostratigraphic units: middle sand unit (Lower Safa) which is a gas bearing reservoir, upper shale and silt unit (Upper Safa), and a lower shale unit. The upper and lower shale units are the main source rocks (EGPC 1992). Khatatba Formation is overlain by the Upper Jurassic Masajid Formation. It is an argillaceous limestone, rarely fractured but vuggy, dolomitic in part. The Lower Cretaceous lithostratigraphic units are Alam El Bueib, Alamein, and Kharita formations. Alam El Bueib Formation is composed of sandstone, shale, siltstone, limestone and dolomite. It is divided into AEB-1, -2, AEB-3 (A-C-D-E-F-G), AEB-4, -5 (A-B), and AEB-6. Sandstone layers are oil-bearing reservoirs, while shale layers are probable source rocks. AEB-3D unit includes two main oil-bearing sandstone sub-units; D2 and D4 (Fig. 4). It is overlain by a thick shale layer from AEB-3C base. D2 sandstone is widely distributed throughout Qasr field with thickness ranging from 20 to $60 \mathrm{ft}$. (Fig. 5). Alamein formation was deposited in the Aptian marine transgression with dolomite and limestone interbedded with shale (WEC 1984, 1995). It is overlain by Dahab shale in the majority of western desert fields. The Albian Kharita Formation composed of fluvial

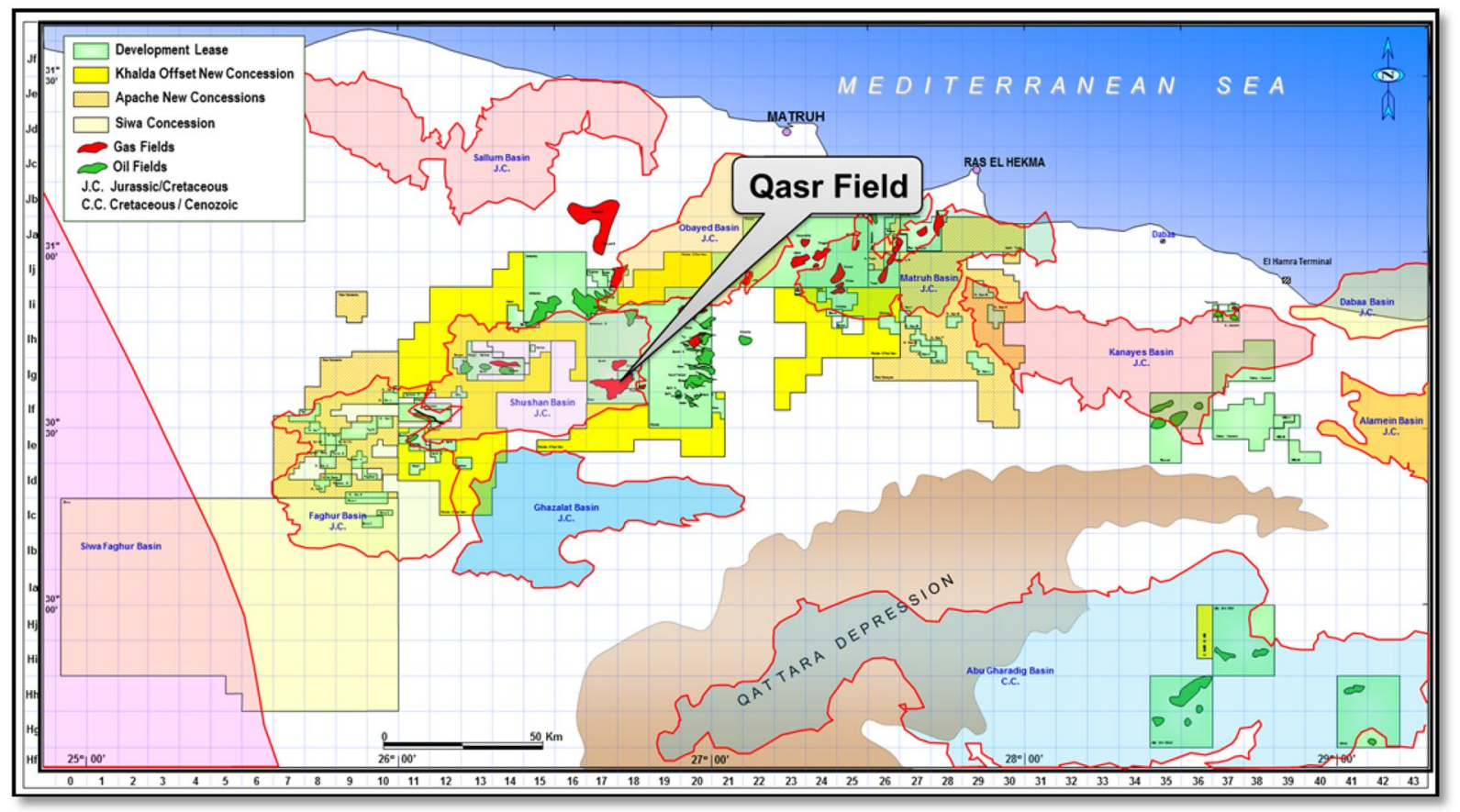

Fig. 1 Northwestern desert concession map showing the location of Qasr field 
coarse to medium grained sandstone and friable sand, interbedded with thin shale and siltstone layers. It is overlain by the Upper Cretaceous Bahariya, Abu Roash and Khoman formations. Bahariya Formation is mostly oil-bearing sandstone, and Abu Roash Formation consists of intercalated limestone and shale, interbedded with thin sandstone, siltstone and anhydrite layers. Khoman Formation is composed of soft chalky limestone and is overlain by the Paleocene to Eocene Apollonia Formation. It is composed of limestone and is a shallow gas reservoir in some locations of the northwestern desert of Egypt (Kamel and Nagy 2014).

\section{History of seismic stratigraphy}

The detection of stratigraphic features on seismic is defined as seismic stratigraphy or seismostratigraphic analysis. Several techniques for seismic-stratigraphic analysis have been proposed by many workers, among them Payton (1977), Berg and Woolverton (1985) and Brown (2004). The analysis is highly facilitated using 3D seismic surveys, but it is still hard to detect thin sandstone reservoirs. The use of 3D seismic for field development was first reported by Tegland
(1977). 3D surveys result in clear and more accurate visualization of the subsurface geology and their costs are rapidly recovered by the drilling of development holes, the increase in recoverable reserves, and by the discovery of isolated reservoirs which may be missed (Sheriff and Geldart 1983). The 3D seismic method increases resolution which is dependent upon wavelength. The seismic wavelength is obtained by dividing velocity and frequency. Seismic velocity increases with depth because the rocks are more compacted. The frequency decreases with depth because the higher frequencies in the seismic signal are more attenuated. The wavelength increases with depth, and the resolution becomes poorer. The limit of separability is equal to onequarter of a wavelength (or half a period) and is simply the bed thickness corresponding to the closest separation of two wavelets of a given bandwidth (Fig. 6). For intervals thinner than one-quarter of a wavelength, the amplitude is progressively attenuated until the limit of visibility is reached, and the reflection signal becomes obscured by the seismic noise (Brown 2004). The limit of visibility depends on the acoustic contrast of the geologic layer of interest relative to the embedding material, the noise in the data, and the shape of the seismic wavelet.

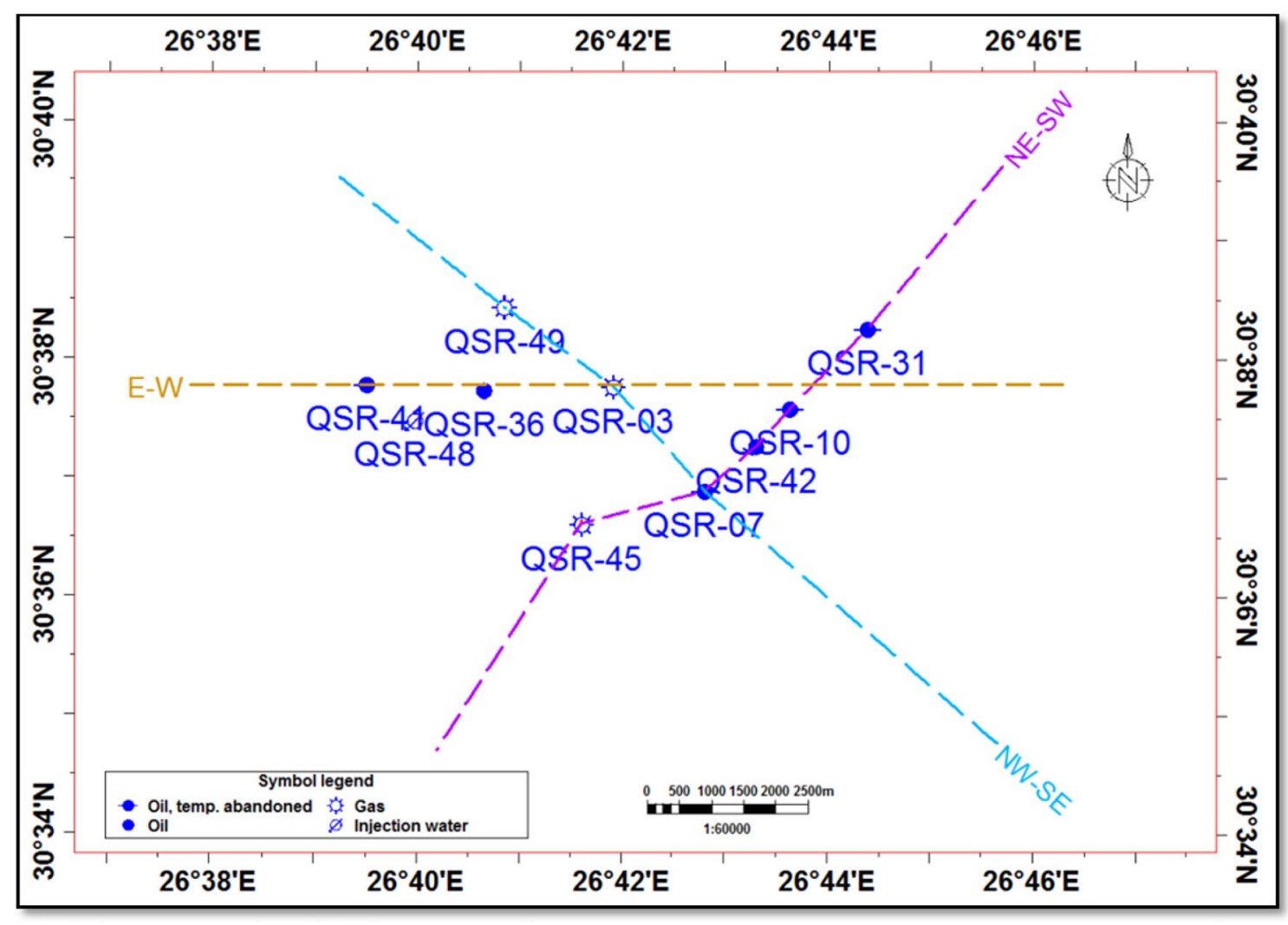

Fig. 2 Location map of Qasr field showing wells and seismic lines 


\section{Seismic resolution and bed thickness}

Seismic resolution is important in stratigraphic analysis and thickness of subsurface strata is mostly affected by resolution. Resolution can be vertical and/or horizontal. The main difficulty in applying seismic techniques to stratigraphy is the lack of suitable resolution in the seismic signal. This means that seismic reflections are unable to resolve most individual layers within the reservoir, but represent a composite response from a large number of layers. The resolving power of seismic wave reflections is dependent on the frequency and wavelength of the seismic pulse induced in the earth. Most seismic wave reflections have dominant frequencies in the range 50-20 Hz (Sheriff 1977). Higher frequencies (shorter wavelengths, and thus higher resolving power) are more strongly attenuated in the earth, which means that lower frequency waves with longer wavelengths and lower resolving power are best transmitted deeper into the subsurface. The difference in resolving power between 50 and $20 \mathrm{~Hz}$ pulses is illustrated in Fig. 7.

Wang et al. (2003) worked on thin sandstone beds in Northwest China, and concluded that 'based on the amplitude, waveform analysis, and modeling, using the amplitude tuning effect, we can identify the pinch-out boundary with its thickness less than $1 / 4 \lambda^{\prime}$. The two types of seismic resolution can be applied on the area of study as follows.

\section{Vertical resolution}

It is defined as a measure of how large an object needs to be in order to be seen on a vertical seismic section. It
Fig. 3 Generalized stratigraphic column of Qasr field (modified after WEC 1984, 1995; EGPC 1992)

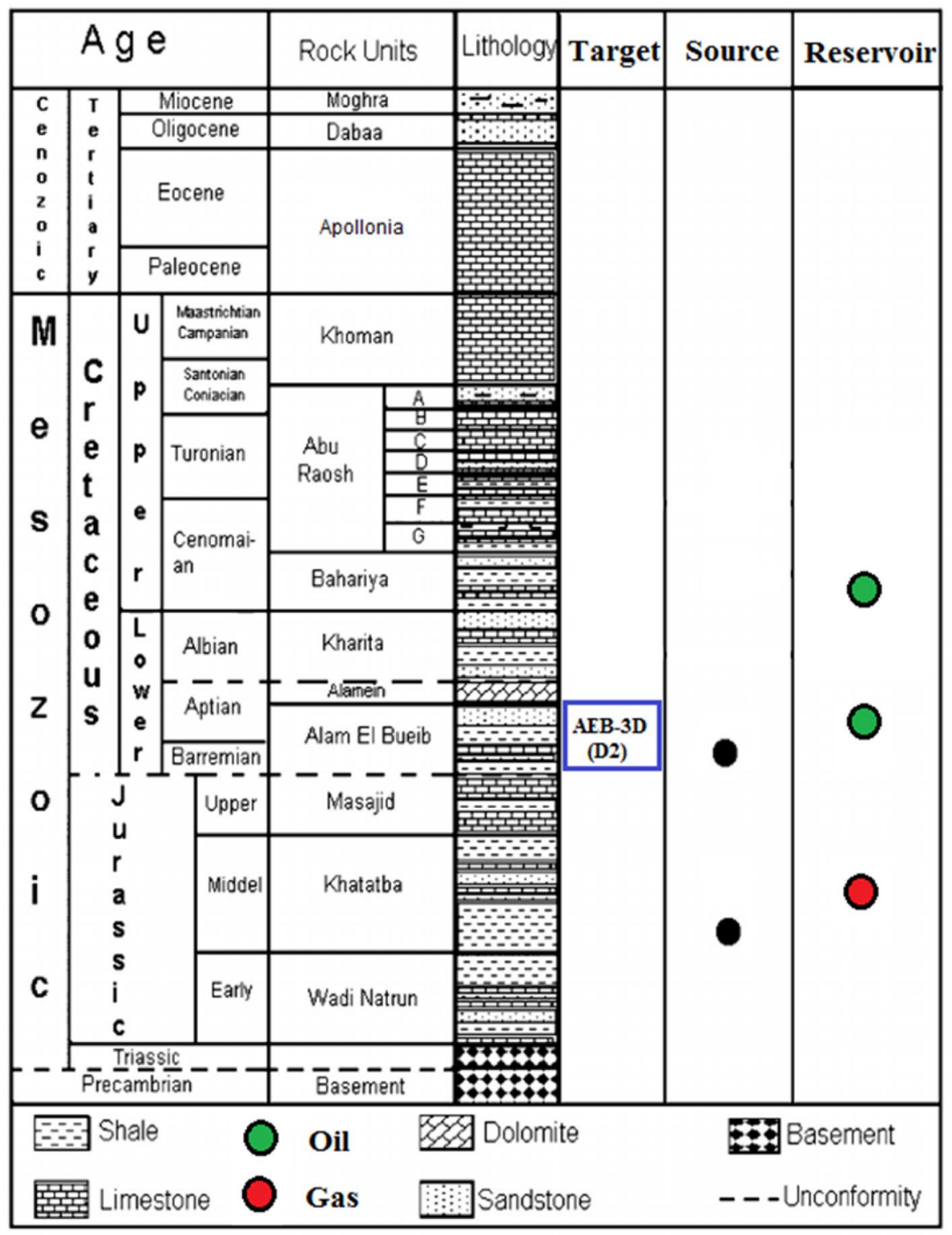


is calculated as a quarter wavelength and layers may be detected when their thickness is below this value. The wavelength is calculated by $\lambda=V / F$ and the vertical seismic resolution is calculated by $\lambda / 4=V / 4 F$, where $\lambda=$ wavelength, $V=$ seismic velocity, and $F=$ seismic frequency.

\section{Horizontal resolution}

The sound wave moving from a source to receiver spread out in three-dimensional circles. Horizontal resolution is derived from the Fresnel zone which is a part of the reflector covered by the seismic signal at a certain depth and is calculated as follows; Fresnel zone before migration $=V$ $(T / F)^{0.5}$, Fresnel zone after migration $=\lambda / 4=\mathrm{V} / 4 F($ Brown 1999), where; $\lambda=$ wavelength, $V=$ seismic velocity, $F=$ seismic frequency, and $T=$ depth in time. In the subsurface, all features with lateral extent greater than the Fresnel zone will be visible. An object can be seen on seismic if it is larger than either the vertical or horizontal resolution. The top of AEB-3D (D2) sand is located at depth 11,000-11,500 ft. and the dominant frequency of the 3D-seismic cube is about $50 \mathrm{~Hz}$, and interval velocity is $13,800 \mathrm{ft}$./s, then seismic resolution $=13,800 /(4 \times 50)=69 \mathrm{ft}$. The thickness of AEB-3D
(D2) sand $\approx \pm 50 \mathrm{ft}$. as depicted from the studied wells, and the sand bodies thicker than $69 \mathrm{ft}$. can be easily detected on seismic cube.

\section{Seismostratigraphic analysis and interpretation}

This work is an attempt to define sand channels and sand bars that are probable reservoirs for field development. The technique used here includes detection of facies on seismic using synthetic seismograms, detection of stratigraphic features on vertical and horizontal time slices, and mapping seismic attributes.

\section{Seismic facies from synthetic seismograms}

The lithological interpretation of electric logs was performed to identify facies in each well. The sonic log recorded in each well was calibrated to check-shot survey, then calibrated sonic with density log and seismic wavelet are used in generating synthetic seismogram. The seismic wavelet was extracted from the seismic cube at well location

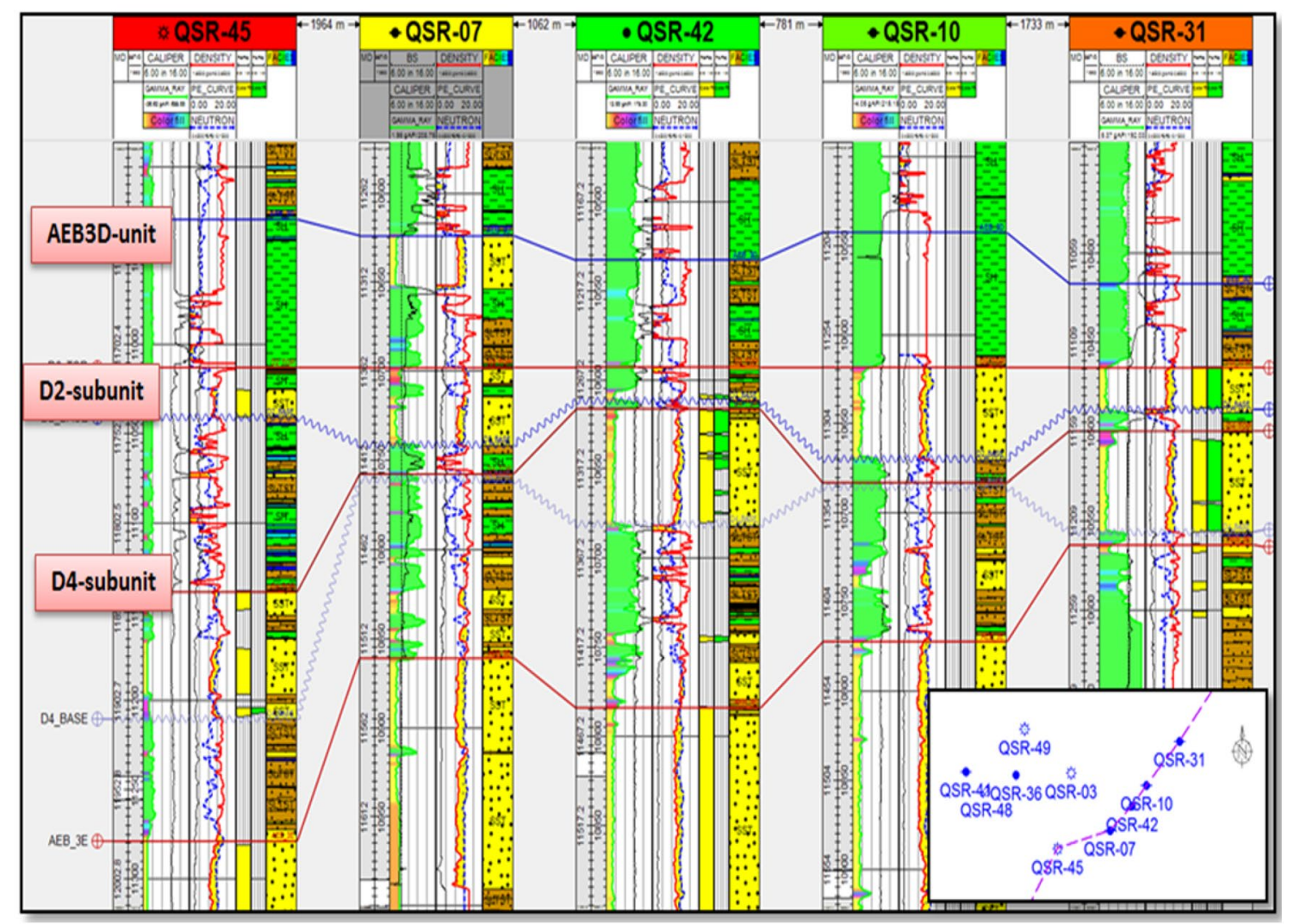

Fig. 4 NE-SW stratigraphic correlation along wells Qasr-31-10-42-07-45. The datum is D2-subunit top. Lithology is shown by colors (yellow for sandstone, green for shale, brown for siltstone, and blue for carbonates)

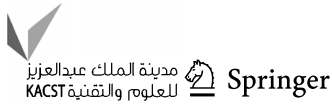




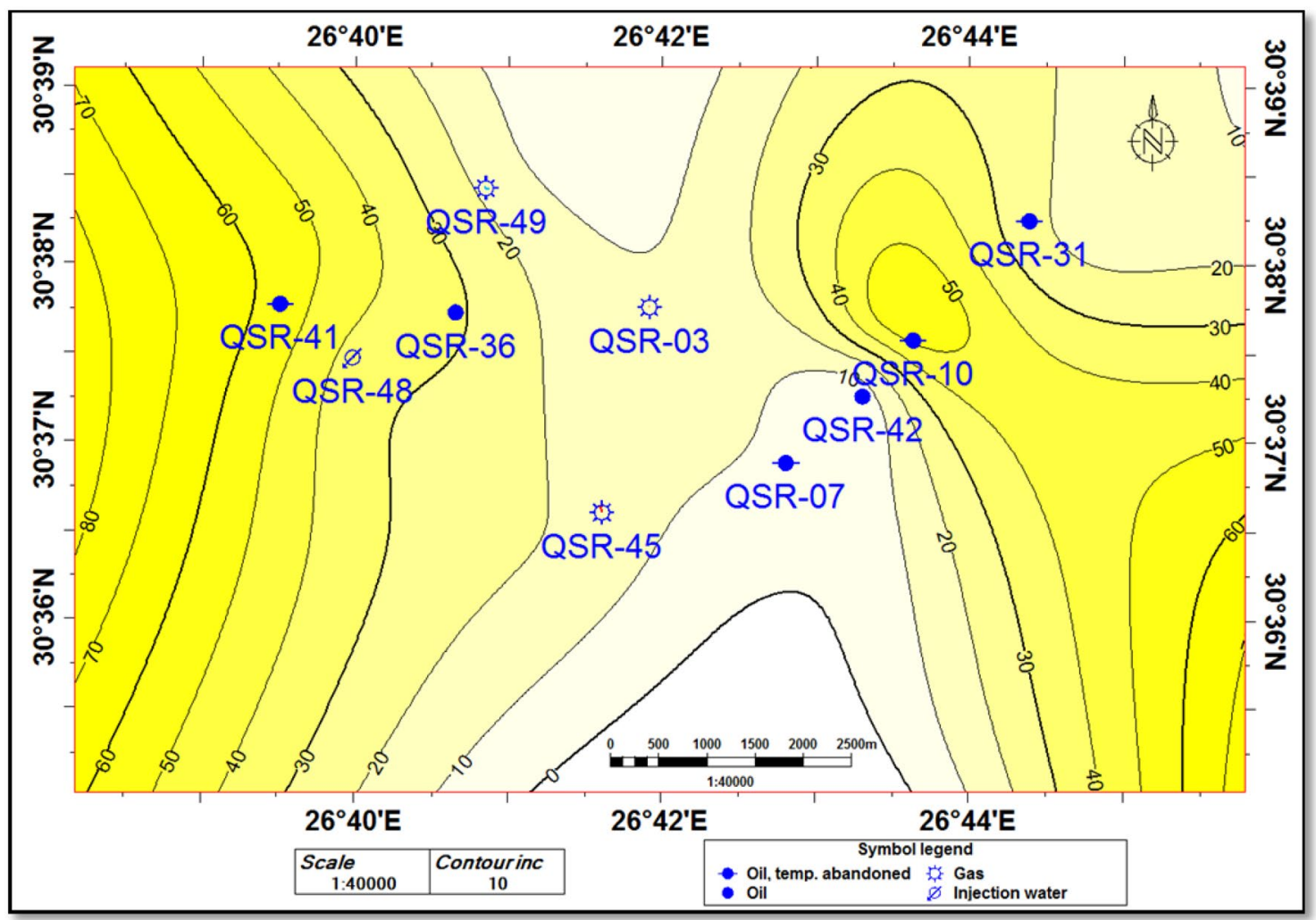

Fig. 5 AEB-3D (D2) sandstone isolith map (ft.)

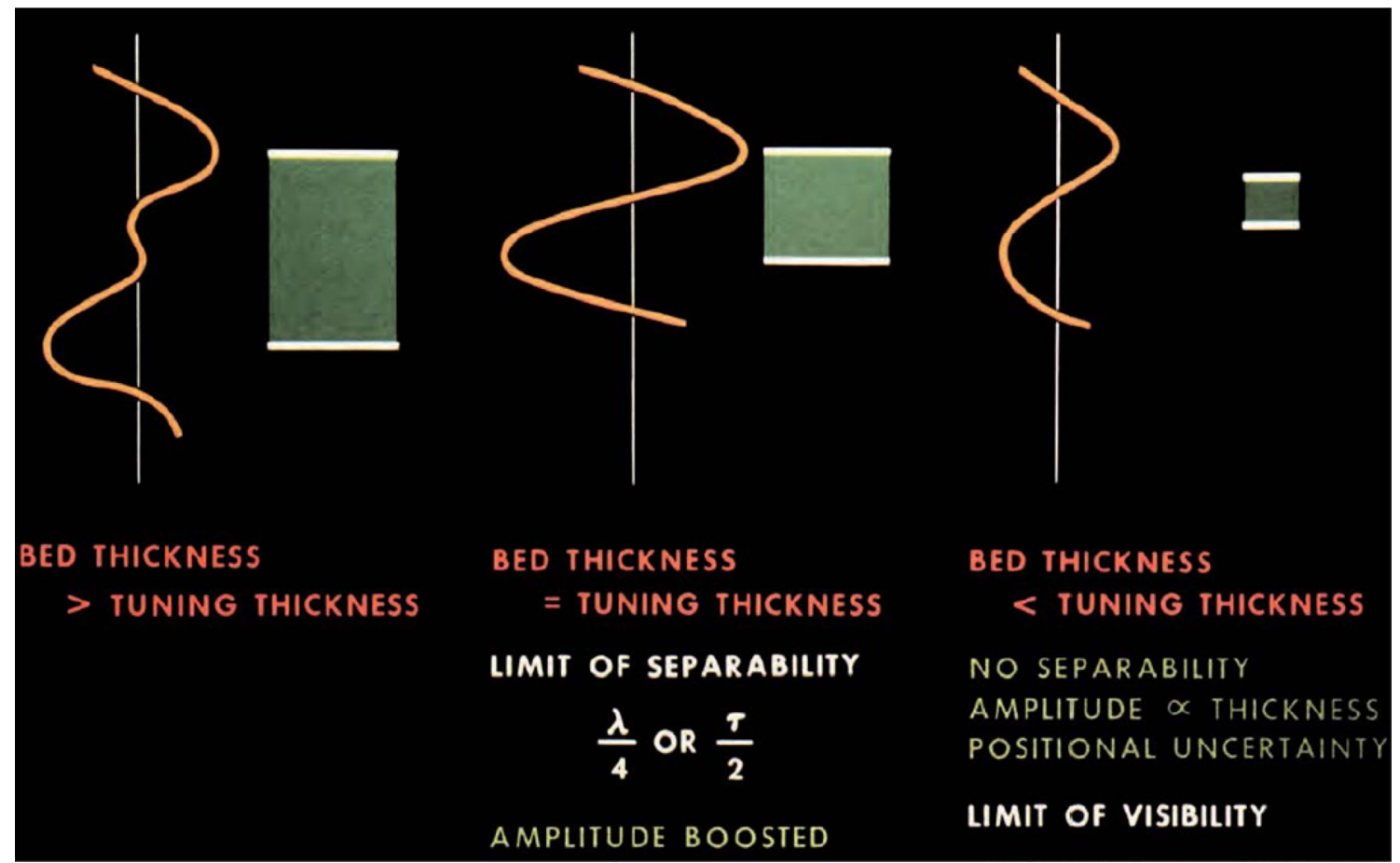

Fig. 6 Resolution of the reflections, from the top and bottom of a bed, is dependent on the interaction of closely spaced wavelets (Brown 2004) 


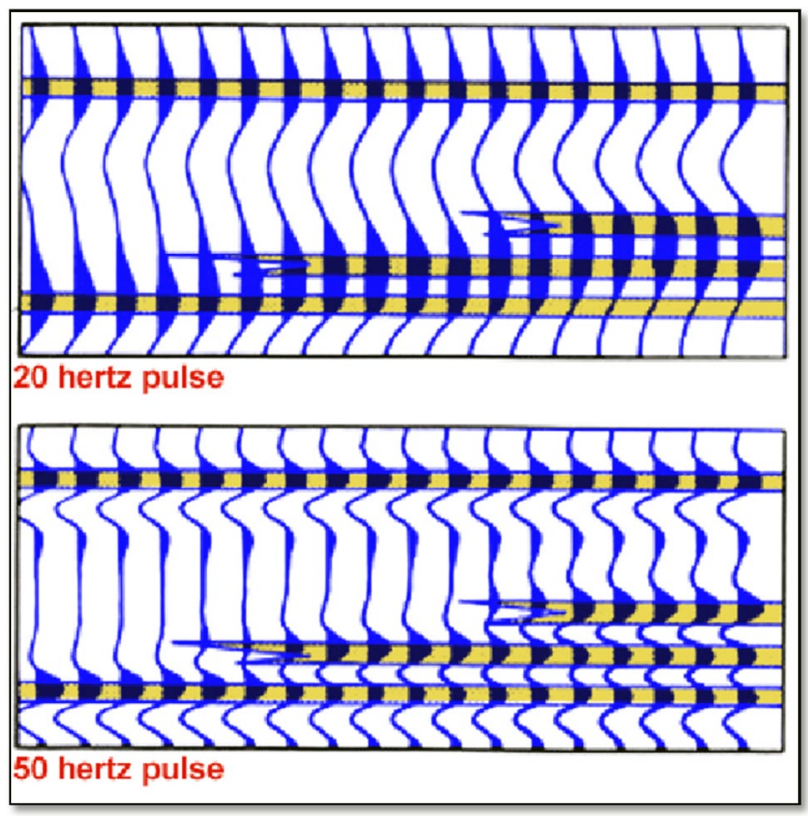

Fig. 7 The difference in resolving power between $50 \mathrm{~Hz}$ and $20 \mathrm{~Hz}$ pulse (after Vail et al. 1977)

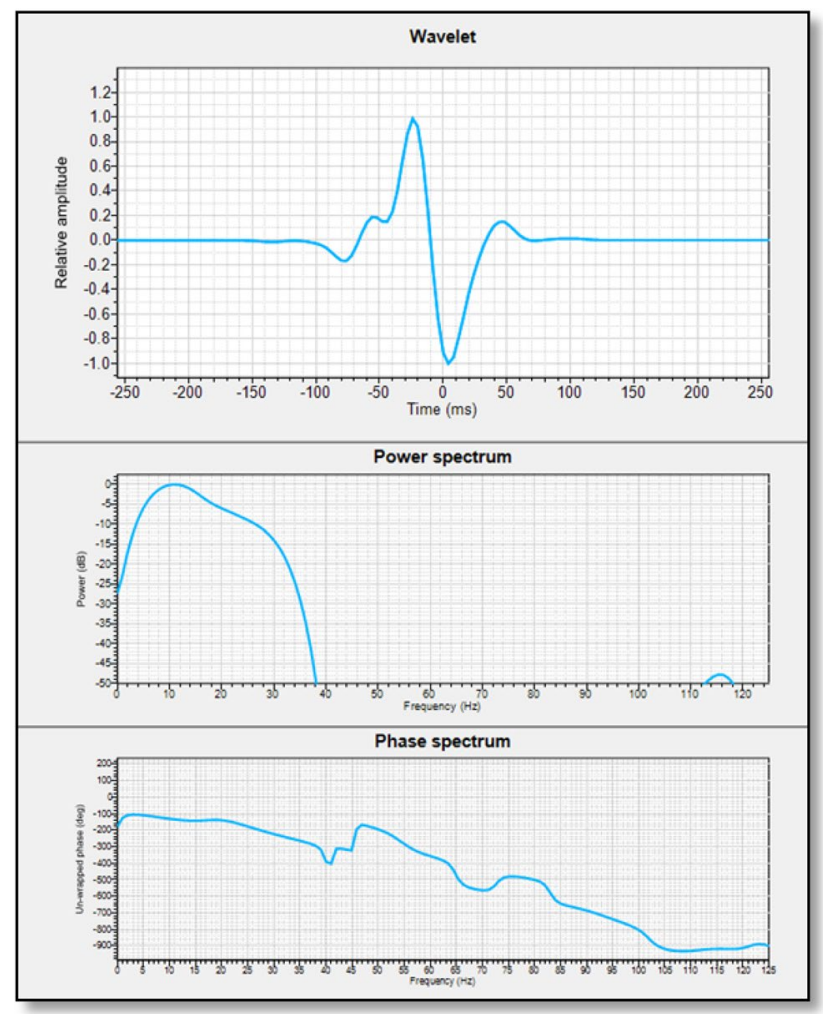

Fig. 8 A zero-phase wavelet used for synthetic generation at a zero phase, 10-20-40-60, reverse polarity (a trough equals compression) wavelet with a $100 \mathrm{~s}$. Automatic gain control (AGC) produced an optimal tie for all wells in the study area (Fig. 8). Synthetic seismograms from four wells, namely Qasr-3, -07, -36 and Qasr-41, used as example and showed bulk time shift up to $\pm 10 \mathrm{~ms}$ (Figs. 9, 10,11, 12). A comparison between a generated synthetic to actual seismic data shows fair-to-good match. Four facies were identified from core and composite logs (COREX 1997); these are channel sand for sandstone lithology (yellow color), flood plain for siltstone lithology (brown color), lagoonal mud for shale lithology (green color), and marine carbonate facies for limestone and dolomite lithologies (blue color). The marine carbonate facies showed higher interval velocity and negative (red) seismic amplitude (Alamein-B and AEB-2). Shales underlain Alamein-B carbonates and siltstones underlain AEB-2 carbonates showed positive amplitude (blue). This is clearly observed in synthetic seismograms of wells Qasr-03,-07, and -36, that are correlated to seismic inlines passing through each well. Shales at AEB-3C base showed low interval velocity and positive (blue) seismic amplitude. These shales overlay the sandstones of AEB-3D unit that showed slightly higher interval velocity with clear negative (red) seismic amplitude. Higher reflection coefficient is observed at the interfaces between carbonate and clastics, and between shale and sandstone. The thickness of AEB3D (D2) sandstone in the studied wells ranges between 12 and $53 \mathrm{ft}$. (Table 1). The interval velocity ranges between 13,180 and $15,151 \mathrm{ft} . / \mathrm{s}$, and sonic values show inverse relation with the bulk density of the sandstone. The detection of AEB-3D (D2) sandstones on seismic is of major interest since it is an important reservoir, but the major problem is that it is thin $( \pm 50 \mathrm{ft}$.$) .$

\section{Detection of Sandstone on seismic sections}

Seismic sections having reflections are displayed as positive amplitudes (blue color, black wiggles), and negative amplitudes (red color, transparent wiggles). Distinguishing different colors is important, since it is an indication of different lithologies. The reflection at shale/sand interface at top D2-sand reservoir shows positive amplitude above and negative amplitude below, as depicted from synthetic seismograms. This is because the 3D seismic data have a reverse polarity, which means a trough equals a compression. Besides, the marine shale facies at base AEB-3C unit has lower acoustic impedance than the underlying sandstone of D2-unit, where a vertical seismic section intersects a stratigraphic feature the interpreter can normally find a 


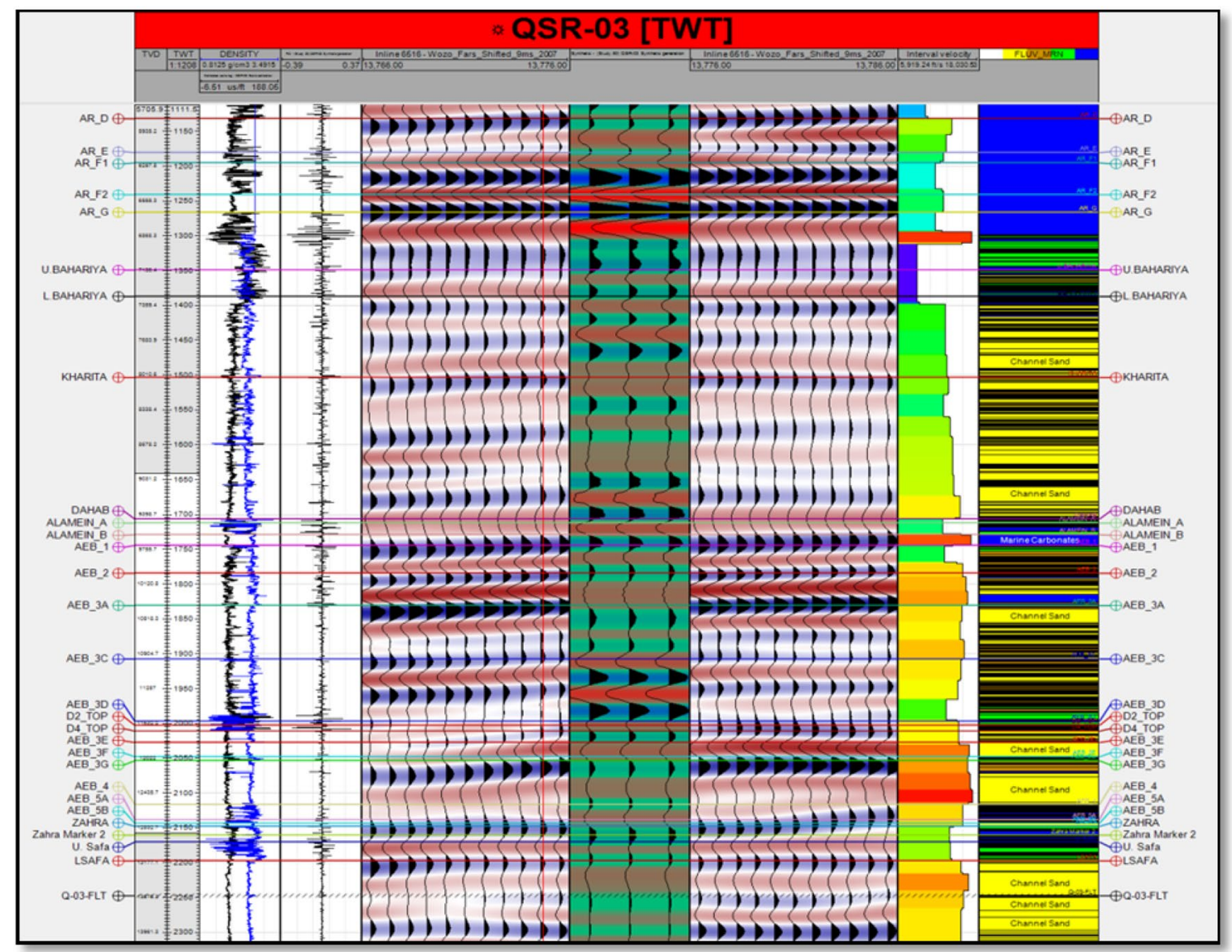

Fig. 9 Synthetic seismogram of well Qasr-03, depth-two-way-time (TWT) relationship with linear depth scale. Note that the sandstone is shown by yellow color on the lithology column to right

small amplitude or character anomaly, and the D2-sandstone is represented by negative (trough) amplitude (Figs. 13, $14,15)$. In contrast, a horizontal section reveals the spatial extent of an anomaly (Fig. 16). A shape or pattern which is unrelated to structure may prove to be interpretable as a depositional, erosional, lithological or other feature of significance. (Brown 2004). The seismic two-way-time is displayed vertically on vertical seismic section. Mapping of the times produces a structure map, while mapping of the amplitudes produces a horizon slice. The amplitudes can be extracted from the data after time tracking, but it is possible to extract the amplitudes parallel to the tracked horizon and shifted by a chosen number of milliseconds. The technique used here can be summarized as follows:

- Select vertical seismic section passing by two or more wells.

- Overlay synthetic seismogram and lithology in each well.

- Display seismic wiggles for positive and negative amplitudes. 


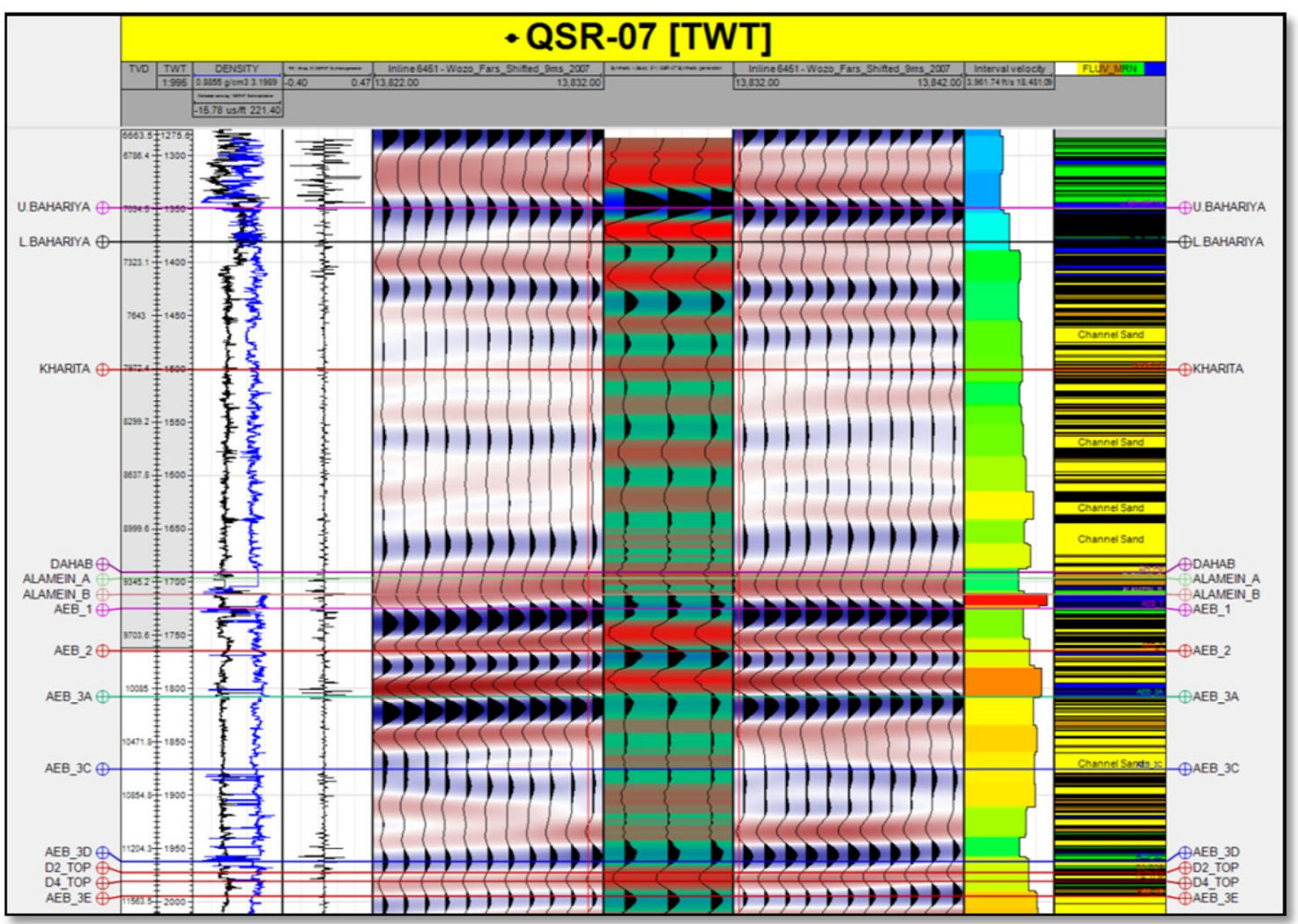

Fig. 10 Synthetic seismogram of well Qasr-07, depth-TWT relationship with linear depth scale. Note that the sandstone is shown by yellow color on the lithology column to right

- Follow-up amplitudes between wells, and record subtle changes.

Figure 13 shows E-W seismic section along wells Qasr41-36-03. The lithology at unit AEB-3C base is shale (green color) and shows strong positive amplitude on seismic section (black wiggles) and synthetic seismograms (blue color) in all wells. The sand lithology (yellow color) in the D2 unit shows clear negative amplitude on seismic section, and synthetic seismograms (transparent wiggles, red color) in all wells. The top of D2 unit, obtained from time interpretation, is displayed along the section (yellow dashed line). Along top D2-unit, the seismic negative amplitude is continuous and strong between wells Qasr-41 and Qasr-36, which may indicate the continuity of the sand unit between the two wells. The D2-sand unit negative amplitude is attenuated clearly towards well Qasr-03, with a dominance of strong positive amplitude, due to the fact that sand thins dramatically and shale prevails. The surface of D2 unit across wells does not show any structural effect and the symmetrical Plano-convex upward geometry across wells Qasr-41 and Qasr-36 could be a channel-like facies (Metwalli and Bakr 2007).

Figure 14 shows SW-NE seismic section along wells Qasr-07-42-10-31. The negative seismic amplitude, from high to low impedance or vice versa, is clear and continuous along wells Qasr-07, -42 and Qasr-10. The plan to symmetrical convex upward geometry appears across wells Qasr-42 


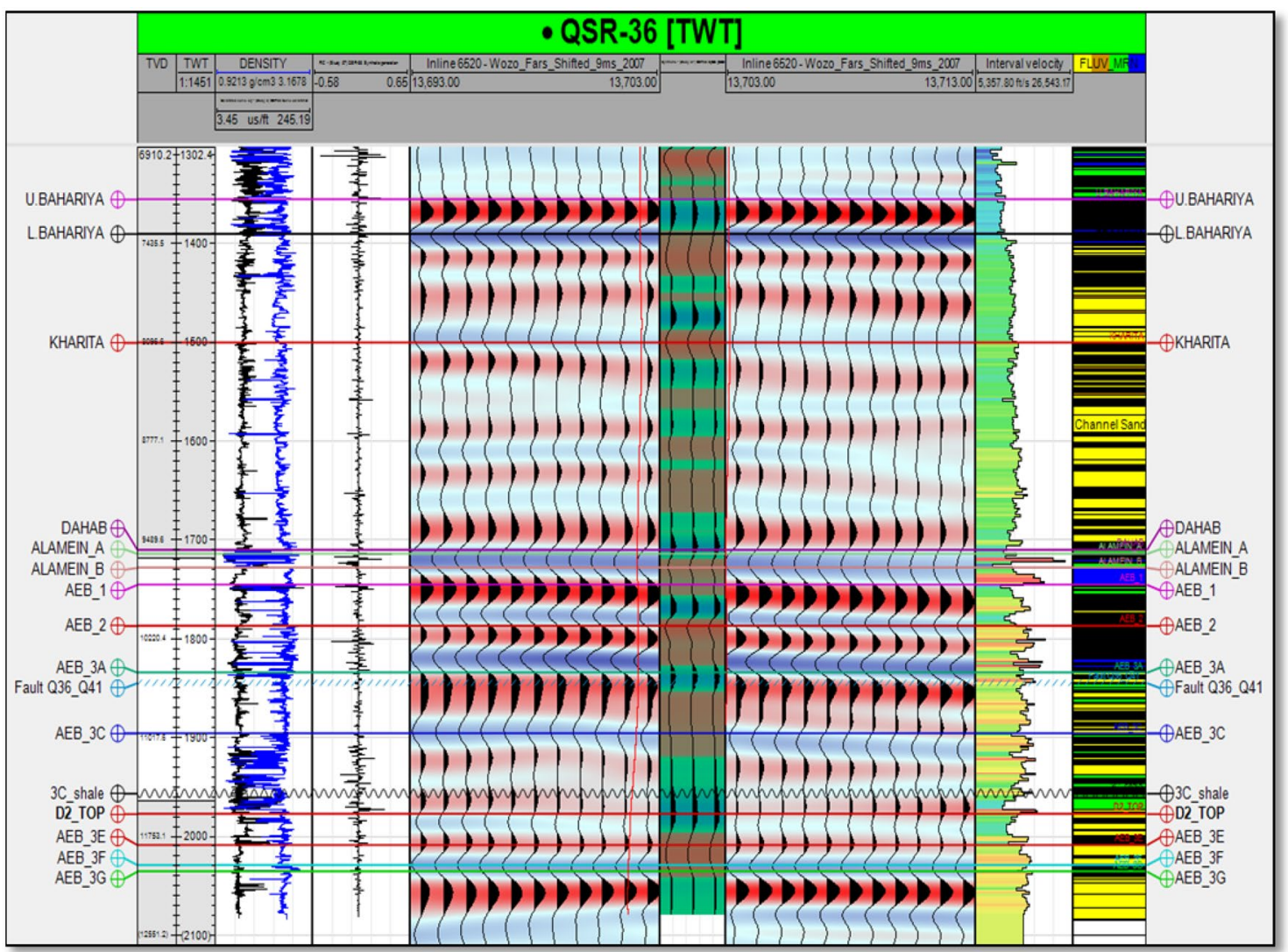

Fig. 11 Synthetic seismogram of well Qasr-36, depth-TWT relationship with linear depth scale. Note that the sandstone is shown by yellow color on the lithology column to right

and Qasr-10, which may indicates a channel-like facies. The seismic reflectors change from positive to negative along top D2-unit between wells Qasr-10 and Qasr-31, and this may be due to lithological variation between sand, shale and siltstone across these wells. The variation in lithology, as depicted from well data and changing seismic signature, may be due to a braided channel system or deposition in a transitional continental to marginal marine environment.

A NW-SE seismic section, across wells Qasr-49-03-07 (Fig. 15), shows the distortion of the negative amplitude and prevalence of strong positive amplitude between wells. This may be due to the fact that sand disappears and/or thins progressively between and towards wells. The D2-sand unit is clearer at well Qasr-49 with strong negative amplitude (red color). It is thins at wells Qasr-03 and Qasr-07, with the dominance of shale and shaly sandstones with strong positive reflector. The extent and geometry of this sandstone facies can be measured along horizontal time sections, while thicknesses are obtained from well data. The top of D2 horizon is detected between times 1990 and $2010 \mathrm{~ms}$. along vertical sections with the studied wells. The proper time at which horizontal seismic section is selected is a matter of trial and error, and the resultant time slice should have a strong correlation with other geological and geophysical data. The seismic horizontal section is selected at time $-1995 \mathrm{~ms}$ (Fig. 16). The gradational red-white-blue amplitude was selected for variation in lithology, density and interval velocity. Blue color stands for peak, mostly shale, and red color for trough amplitudes, mostly sandstone.

Figure 17 shows the same Seismic horizontal section, without gradation in color of amplitudes. The positive amplitude is displayed in blue color, while negative amplitude is 


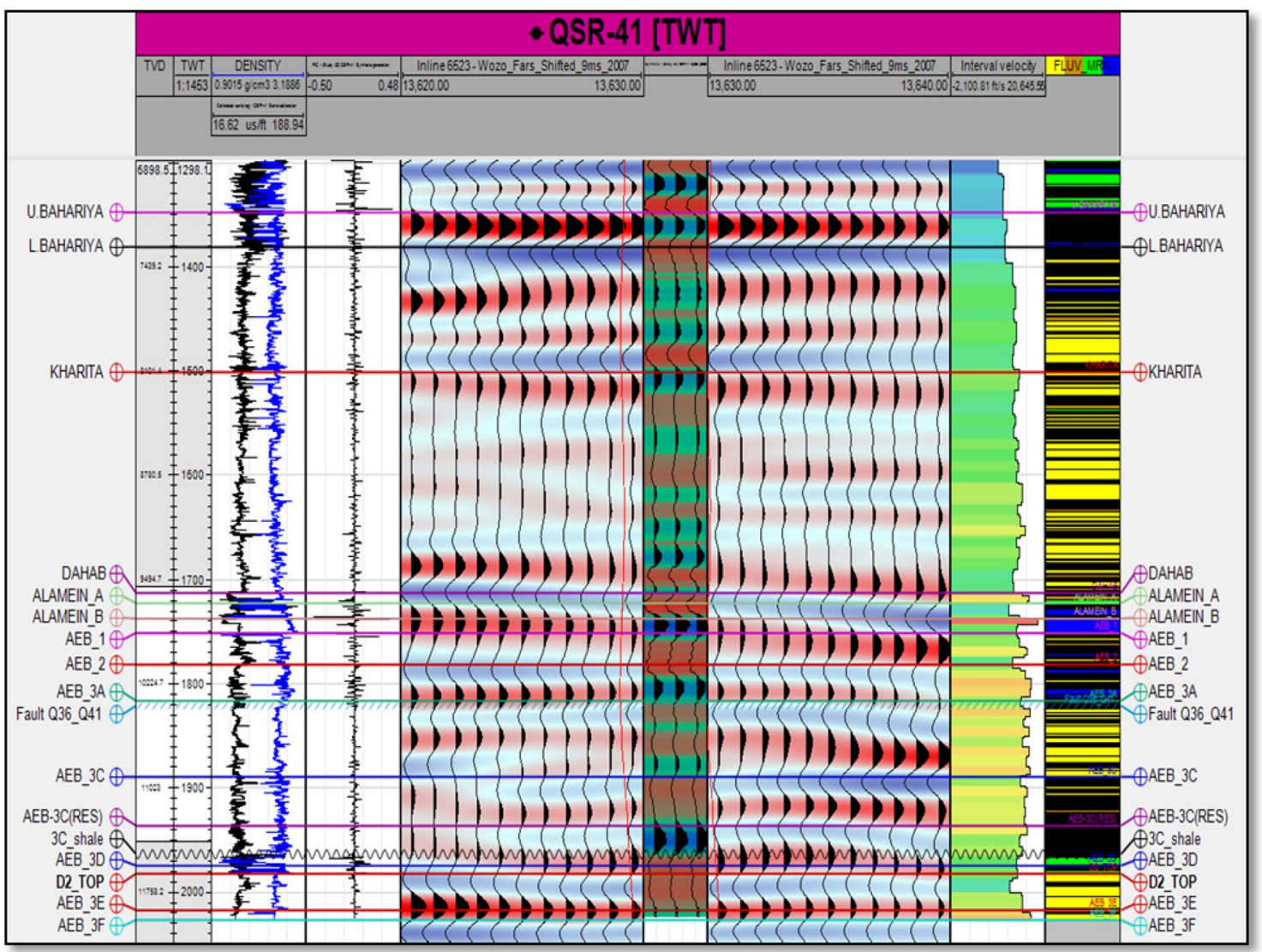

Fig. 12 Synthetic seismogram of well Qasr-41, depth-TWT relationship with linear depth scale. Note that the sandstone is shown by yellow color on the lithology column to right

displayed in red color. The red color in this section refers to the channel-like sandstone facies.

According to this section we have two channels. The first channel oriented NE-SW across wells Qasr-31-10-42 and Qasr-07 with a length $4.5 \mathrm{~km}$ long and width $\sim 425 \mathrm{~m}$. The second channel oriented NNE-W across wells Qasr-36 and Qasr-41 with a length $3.6 \mathrm{~km}$ long and width $\sim 500 \mathrm{~m}$. The thickness of sand ranges between 30 and $60 \mathrm{ft}$. as depicted from well data.

Figure 18 shows the same seismic horizontal section overlain by isolith sand contour lines. The distribution of sandstone seismic facies shows a good correspondence with the distribution of sandstone thickness obtained from well data.

\section{Mapping of seismic attributes}

Several attributes have been tested along the thin AEB-3D (D2) sand unit, among them the relative acoustic impedance attribute. It shows apparent acoustic contrast and indicates sequence boundaries, unconformity surfaces, and discontinuities. It can also indicate porosity in the reservoir (Schlumberger 2011). The relative acoustic impedance AEB-3D (D2) map (Fig. 19) shows lower values in areas of 


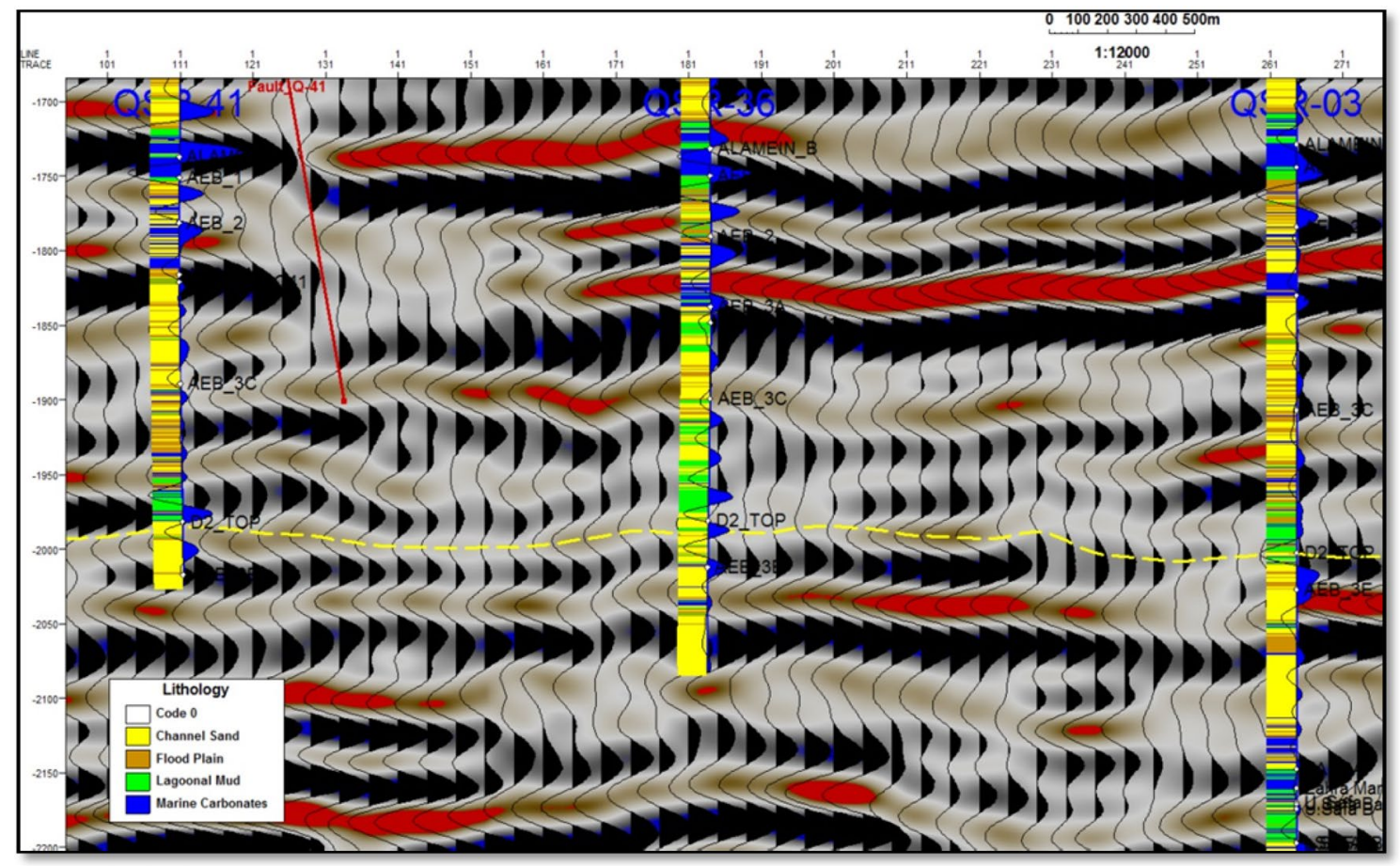

Fig. 13 E-W seismic section along wells Qasr-41-36-03. Lithology and synthetic positive amplitude (blue) are displayed in each well. Amplitude wiggles are displayed (black wiggles are positive amplitudes). Top D2 sand unit in dashed yellow line

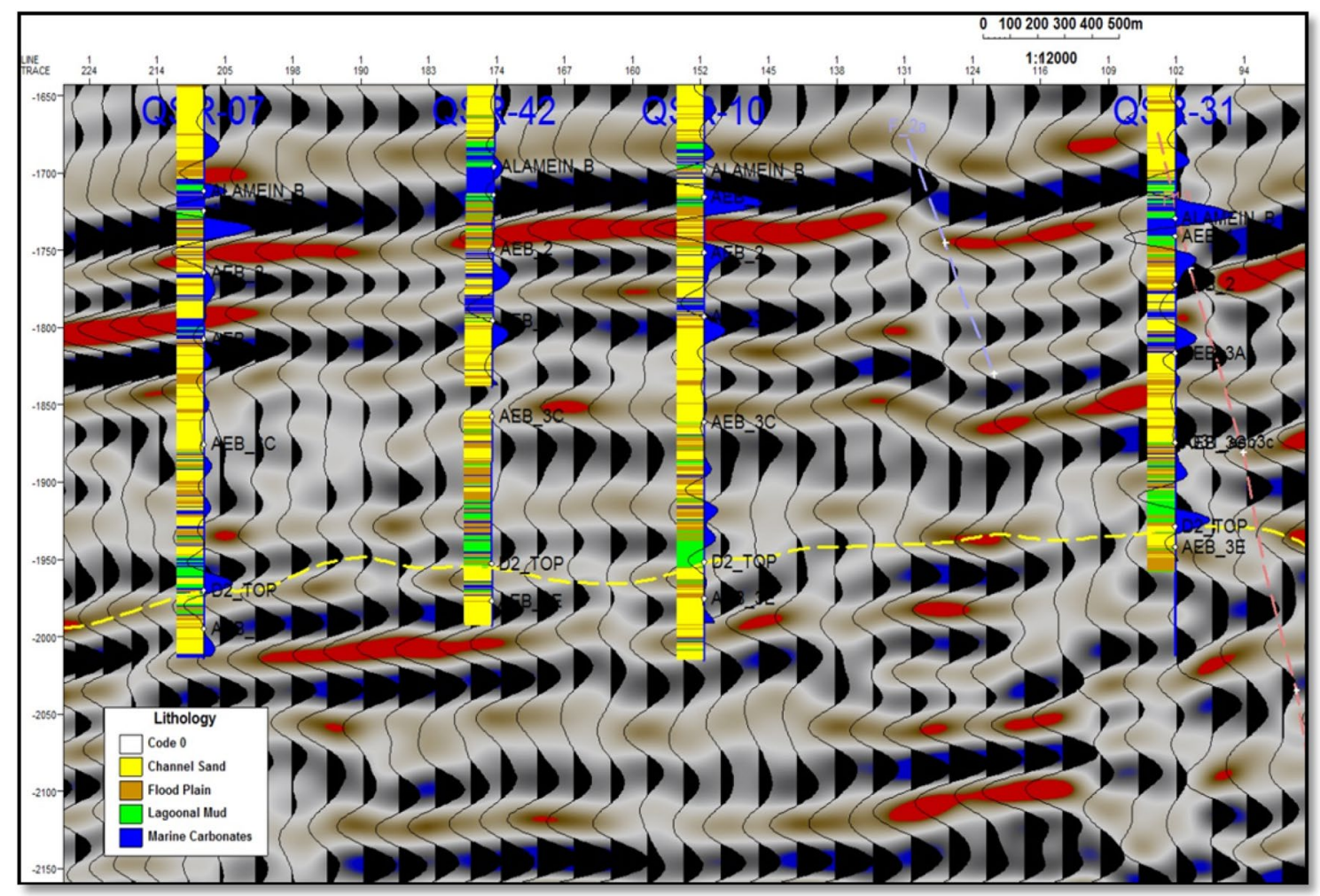

Fig. 14 NE-SW seismic section along wells Qasr-07-42-10-31. Lithology and synthetic positive amplitude (blue) are displayed in each well. Amplitude wiggles are displayed (black wiggles are positive amplitudes). Top D2 sand unit in dashed yellow line

1

Springer 


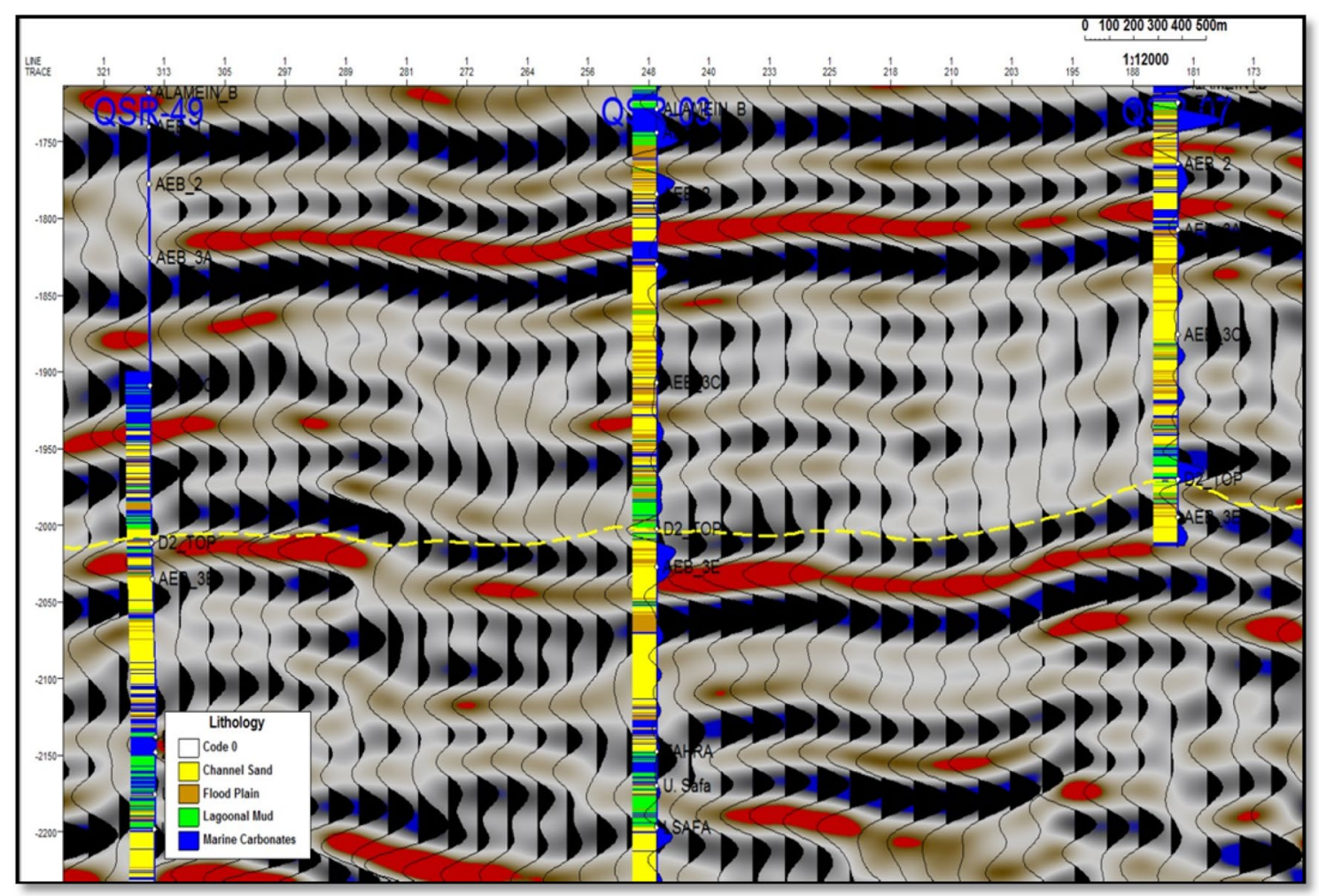

Fig. 15 NW-SE seismic section along wells Qasr-49-03-07. Lithology and synthetic positive amplitude (blue) are displayed in each well. Amplitude wiggles are displayed (black wiggles are positive amplitudes). Top D2 sand unit in dashed yellow line

most productive wells (yellow and green colors), and this value continues to southwest direction. On the other hand, higher values tend to be in areas of low or non-production, due to thinning or absence of the reservoir.

\section{Summary and conclusion}

Qasr Field is one of the important oil-producing fields in the northwestern desert of Egypt, where the Lower Cretaceous Alam El Bueib Formation has several oil-bearing sandstone reservoirs. These reservoirs are usually thin (20-60 ft. thick). The detection of thin sandstone reservoirs on seismic sections is a matter of seismic resolution and bed thickness.
Usually, layers thinner than $50 \mathrm{ft}$. thick cannot be visualized on vertical seismic sections. It was a challenge to follow unit AEB-3D (D2) sandstone channels and bars using available horizontal and vertical seismic sections coupled with other well logs and well data. Mapping of the relative acoustic impedance attribute showed that unit AEB-3D (D2) has lower values in areas of most productive wells, and this value continues to southwest direction. On the other hand, higher values tend to be in areas of low or non-production, due to thinning or absence of the reservoir. Final results stated that, although unit AEB-3D (D2) sandstone is $\pm 50 \mathrm{ft}$. thick, it can be detected, using seismic and other well data, with some efficiency. 


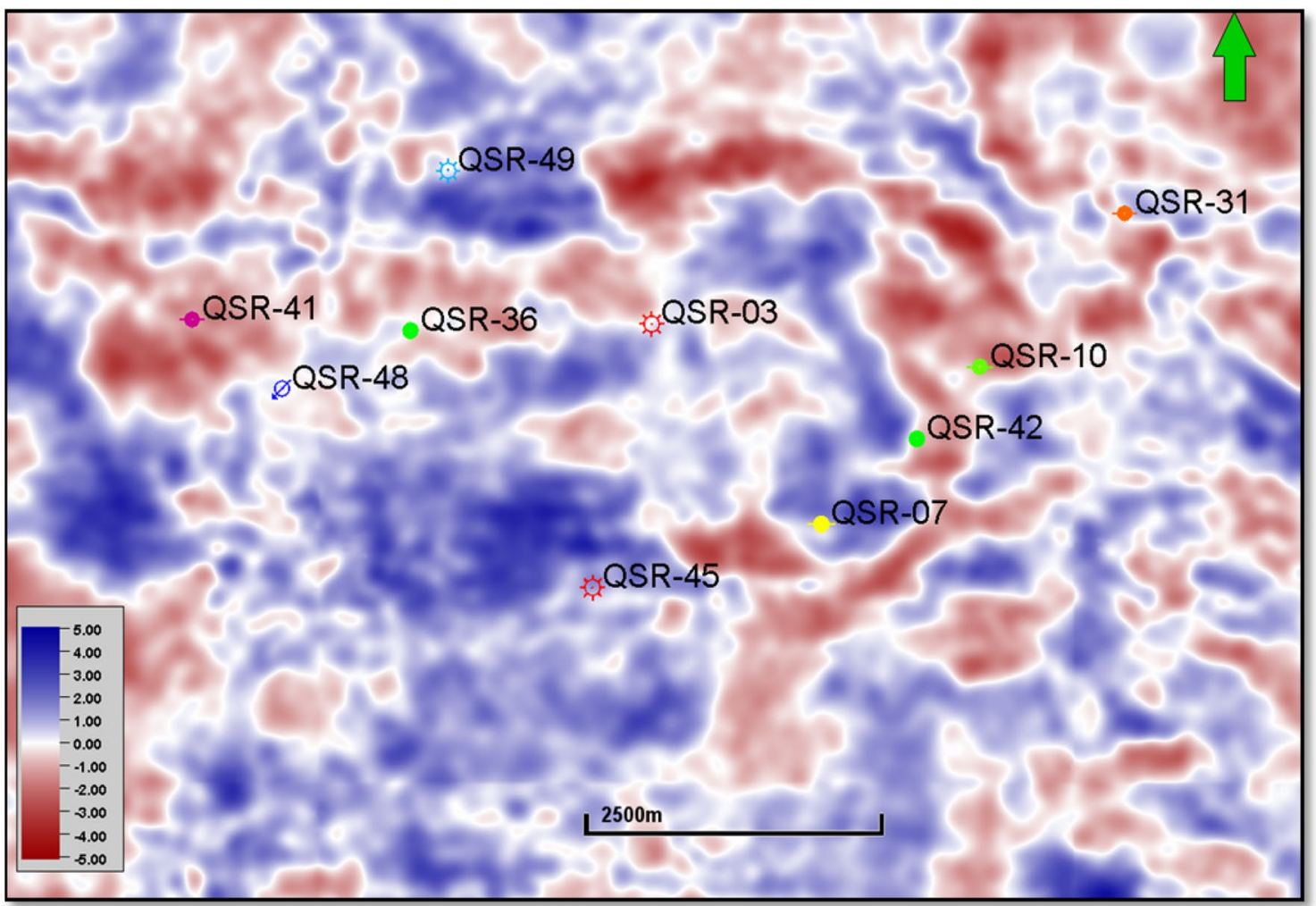

Fig. 16 Seismic horizontal section (time slice) at - $1995 \mathrm{~ms}$. Note the gradational red-white-blue amplitude. Blue color for peak and red color for trough amplitudes

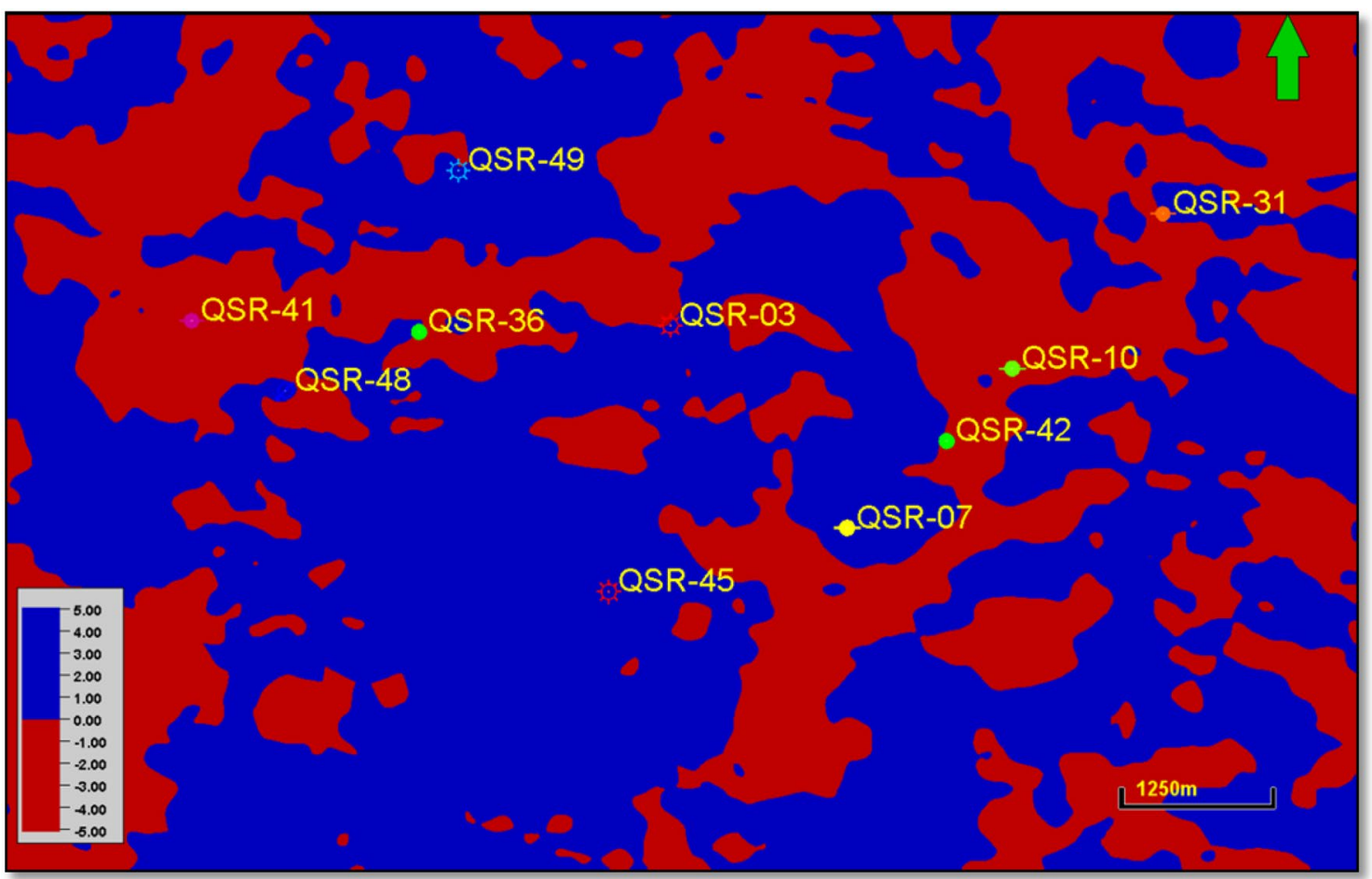

Fig. 17 Seismic horizontal section (time slice) at $-1995 \mathrm{~ms}$. Note the positive amplitude is displayed in blue color, while negative amplitude is displayed in red color 


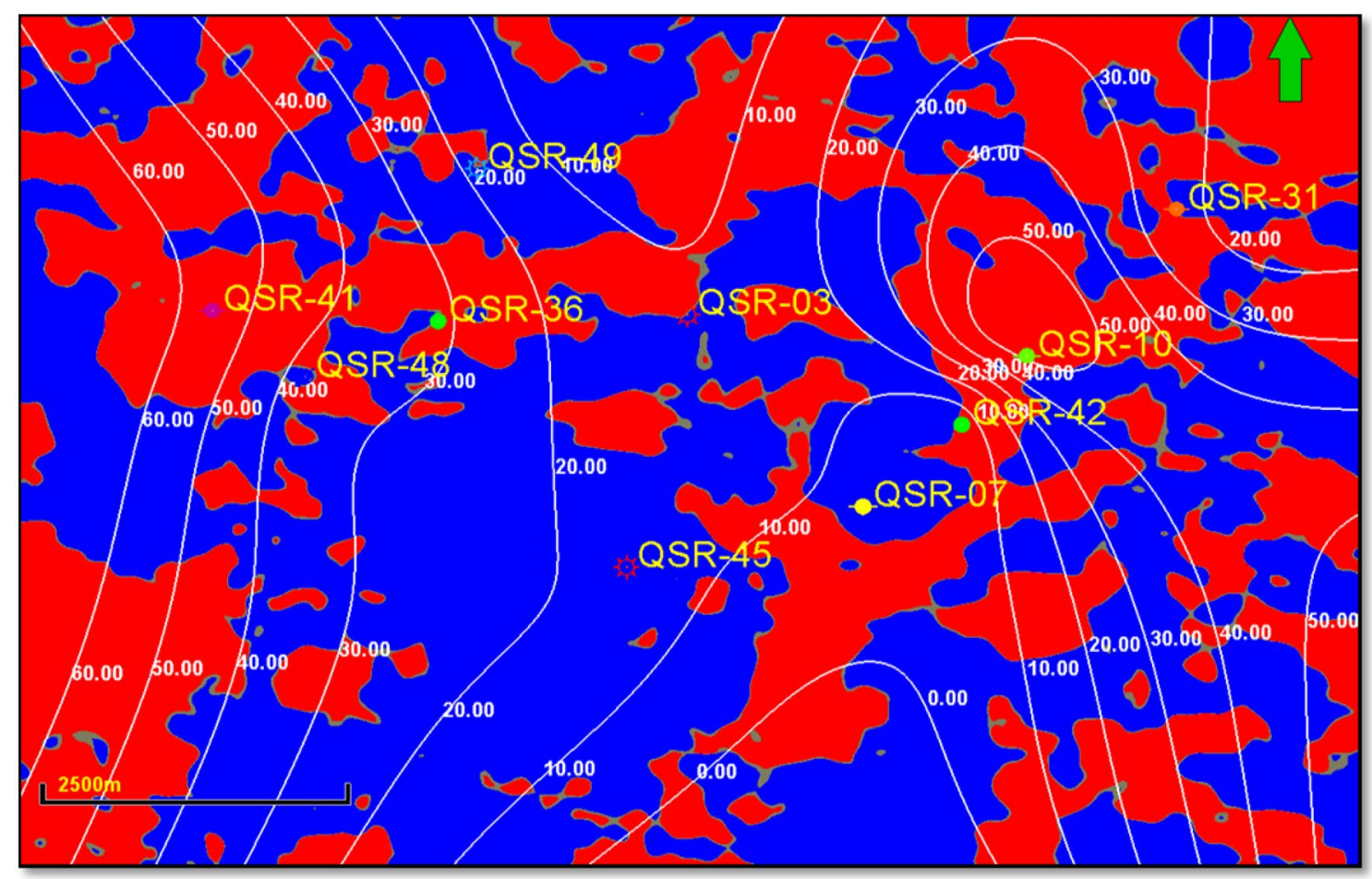

Fig. 18 Seismic horizontal section (time slice) at $-1995 \mathrm{~ms}$. overlain by white isolith sand contour lines (ft.). Positive amplitude is displayed in blue color, and negative amplitude is displayed in red color

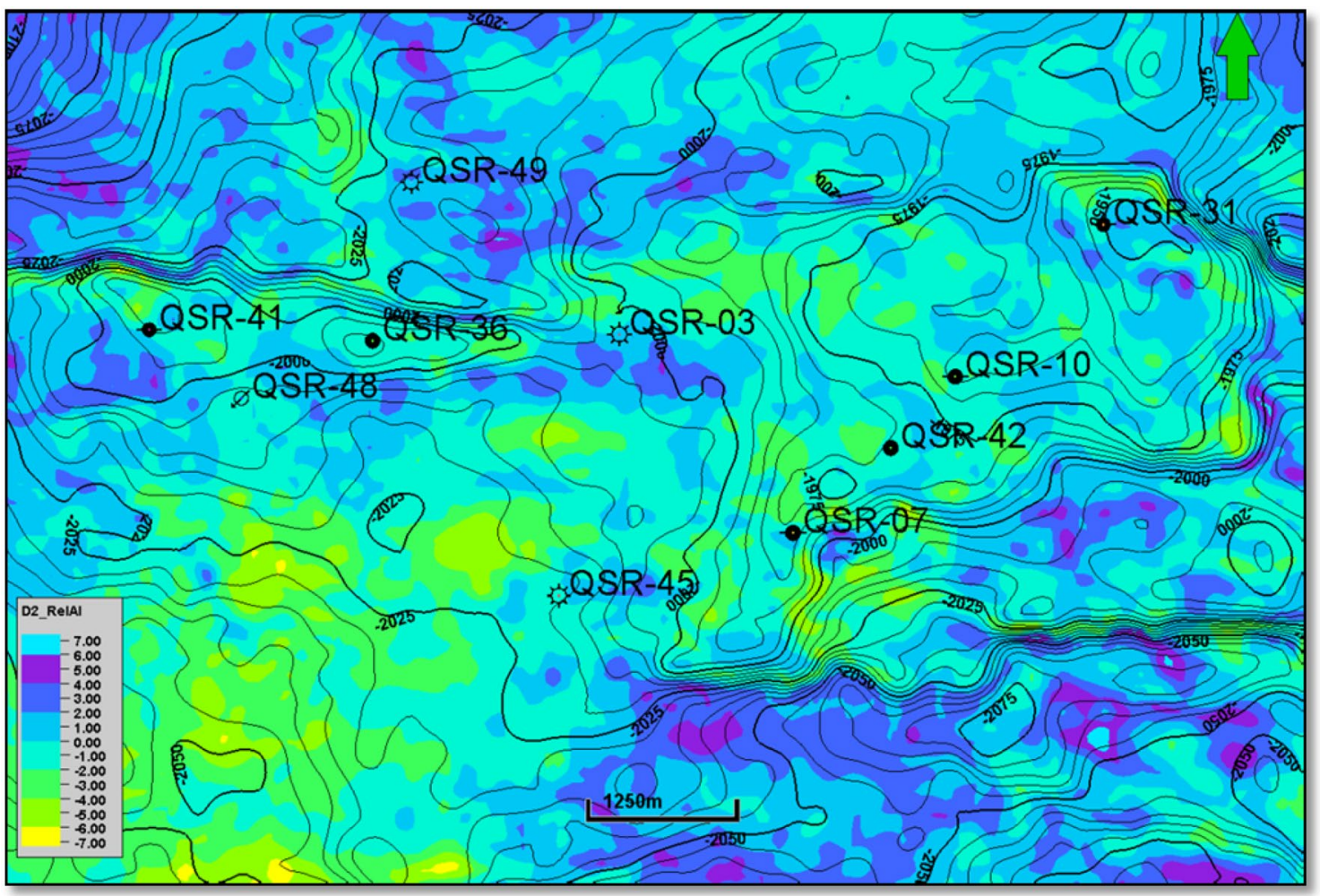

Fig. 19 Relative AI map for unit AEB-3D (D2). The map is overlain by black depth structure contour lines (ft.) 
Acknowledgements Thanks are due to the Egyptian General Petroleum Corporation (EGPC) and Khalda Petroleum Company (KPC), Cairo, Egypt, for their approval and permission to use the material for study.

Open Access This article is distributed under the terms of the Creative Commons Attribution 4.0 International License (http://creativeco mmons.org/licenses/by/4.0/), which permits unrestricted use, distribution, and reproduction in any medium, provided you give appropriate credit to the original author(s) and the source, provide a link to the Creative Commons license, and indicate if changes were made.

\section{References}

Berg OR, Woolverton DG (1985) Seismic stratigraphy II: an integrated approach to hydrocarbon exploration. AAPG Memoir No. 39. AAPG, Tulsa

Brown AR (1999) Interpretation of three-dimensional seismic data, 5th edn. AAPG Memoir 42. AAPG, Tulsa, p 514

Brown AR (2004) Interpretation of three-dimensional seismic data, AAPG Memoir 42, SEG Investigation in Geophysics, No. 9. AAPG, Tulsa

COREX (1997) Sedimentology, reservoir zonation, petrology and reservoir quality of the ALAM EL BUEIB-1 and 3D units, TUT field, Western Desert, Khalda Petroleum Company Internal Report

EGPC Egyptian General Petroleum Corporation (1992) Western Desert, oil and gas fields. In: EGPC 11th petroleum exploration and production conference, Cairo

El Awdan A, Youssef F, Moustafa AR (2002) Effect of Mesozoic and Tertiary Deformations on hydrocarbon exploration in the northern Western Desert, Egypt. Amer. Assoc. Petrol. Geol. Int. Meeting, Cairo

Kamel T, Nagy H (2014) Exploration and development challenges of a tight carbonate gas play in the middle Eocene Apollonia Formation, Western Desert of Egypt. AAPG Search and Discovery Article \#90188 @GEO-2014, 11th Middle East Geosciences Conference and Exhibition, 10-12 March 2014, Manama

Metwalli FI, Bakr AM (2007) Seismostratigraphic analysis of the Alam El Bueib Reservoir Sand, South Umbarka Area, Western Desert, Egypt. ISESCO Sci Technol Vis 3(3):67-78
Metwalli FI, El Maadawy KG (2005) Seismic signature modeling for the Lower Cretaceous Reservoir Sands, South Umbarka Area, Western Desert, Egypt. EGS J 3(1):1-15

Moustafa AR (2008) Mesozoic-Cenozoic Basin Evolution in the Northern Western Desert of Egypt. In: 3rd symposium on the sedimentary basins of Libya (The Geology of East Libya), vol 3, pp 29-46

Othman AA, Metwalli FI (2000) Depositional model construction and paleoenvironmental scrutinization of Alam El Buieb Formation, Shushan Basin, Western Desert, Egypt. Al-Azhar Bull Sci 11(2):39-62

Payton CE (1977) Seismic stratigraphy—applications to hydrocarbon exploration. AAPG Mem 26:205-212

Said R (1962) The geology of Egypt. Elsevier, Amsterdam

Schlumberger Information Solutions (2011) Petrel geophysics course. Schlumberger Publication, Houston, pp 224-243

Sheriff RE (1977) Limitations on resolution of seismic reflections and geologic detail derivable from them. AAPG Mem 26:3-14

Sheriff RE, Geldart LP (1983) Exploration seismology; v. 2, dataprocessing and interpretation. Cambridge University Press, Cambridge, $\mathrm{p} 130$

Tegland ER, 1977, 3-D seismic techniques boost field development. Oil Gas J 75(37):79-82

Vail PR, Todd RG, Sangree JB (1977) Seismic stratigraphy and global changes of sea level; part 5. Chronostratigraphic significance of seismic reflections. AAPG Mem 26:99-116

Wang X, Ling Y, Zhang R (2003) The application of the tuning effect to the detection of the thin bed less than $1 / 4 \lambda$-an example in northwest China. In: SEG international exposition and seventythird annual meeting

WEC (Well Evaluation Conference) (1984) Schlumberger (SLB), Egypt

WEC (Well Evaluation Conference) (1995) Schlumberger (SLB), Egypt

Publisher's Note Springer Nature remains neutral with regard to jurisdictional claims in published maps and institutional affiliations. 